\title{
The Mycobacterium tuberculosis serine/threonine kinases PknA and PknB: substrate identification and regulation of cell shape
}

\author{
Choong-Min Kang, ${ }^{1}$ Derek W. Abbott, ${ }^{2}$ Sang Tae Park, ${ }^{1}$ Christopher C. Dascher, ${ }^{3}$ Lewis C. Cantley, ${ }^{2}$ \\ and Robert N. Husson ${ }^{1,4}$ \\ ${ }^{1}$ Division of Infectious Diseases, Children's Hospital Boston, ${ }^{2}$ Division of Signal Transduction, Beth Israel Deaconess \\ Medical Center, ${ }^{3}$ Rheumatology and Immunology Division, Brigham and Women's Hospital, Harvard Medical School, \\ Boston, Massachusetts 02115, USA
}

\begin{abstract}
The Mycobacterium tuberculosis genome contains 11 serine/threonine kinase genes including two, pknA and $p k n B$, that are part of an operon encoding genes involved in cell shape control and cell wall synthesis. Here we demonstrate that $p k n A$ and $p k n B$ are predominantly expressed during exponential growth, and that overexpression of these kinases slows growth and alters cell morphology. We determined the preferred substrate motifs of PknA and PknB, and identified three in vivo substrates of these kinases: PknB; Wag31, an ortholog of the cell division protein DivIVA; and Rv1422, a conserved protein of unknown function. Expression of different alleles of wag31 in vivo alters cell shape, in a manner dependent on the phosphoacceptor residue in the protein produced. Partial depletion of $p k n A$ or $p k n B$ results in narrow, elongated cells. These data indicate that signal transduction mediated by these kinases is a novel mechanism for the regulation of cell shape in mycobacteria, one that may be conserved among gram-positive bacteria.
\end{abstract}

[Keywords: Kinase; DivIVA; peptide library screen; mycobacteria]

Supplemental material is available at http://www.genesdev.org.

Received March 1, 2005; revised version accepted May 24, 2005.

Tuberculosis (TB), caused by the intracellular bacterial pathogen Mycobacterium tuberculosis, remains a major cause of morbidity worldwide (World Health Organization 2002). In addition to the current burden of disease, the ability of $M$. tuberculosis to cause a persistent asymptomatic infection in the human host (latency) is an additional threat, because of the potential for latent infection to become active and cause TB disease. During initial infection and in reactivated disease, $M$. tuberculosis actively replicates in vivo. Latent infection is thought to result from major shifts in gene expression and metabolism, allowing persistence with minimal replication (Manabe and Bishai 2000). The mechanisms by which M. tuberculosis shifts between active replication and the latent state remain largely undefined. An essential component of this process, however, is likely to be the regulation of cell wall synthesis and cell division in response to stimuli encountered in the host.

Reversible protein phosphorylation is a key mecha-

${ }^{4}$ Corresponding author.

E-MAIL robert.husson@childrens.harvard.edu; FAX (617) 730-0254.

Article published online ahead of print. Article and publication date are at http://www.genesdev.org/cgi/doi/10.1101/gad.1311105. nism by which environmental signals are transmitted to cause changes in gene expression in both eukaryotic and prokaryotic cells. In bacteria, two-component systems transmit signals by phospho-transfer from a histidine residue on sensor proteins to an aspartyl residue on response regulator proteins (Magasanik 1995). In eukaryotes, protein phosphorylation occurs mainly on phosphoester residues (serine, threonine, or tyrosine). Although eukaryotic-like protein kinases were identified in the model prokaryote Myxococcus xanthus more than a decade ago (Munoz-Dorado et al. 1991), they were thought to be rare in prokaryotes. Bacterial genome data, however, have revealed eukaryotic-like protein kinase genes in many prokaryotes; the most widely distributed are serine/threonine protein kinases (STPKs) (Leonard et al. 1998).

The M. tuberculosis genome contains genes encoding 11 STPKs, all of which are in the PKN2 family of prokaryotic protein kinases that are most closely related to the eukaryotic STPKs (Cole et al. 1998; Leonard et al. 1998). To date, these kinases have been characterized to a limited extent, and no specific substrates have been identified (Peirs et al. 1997; Av-Gay et al. 1999; Av-Gay and Everett 2000; Koul et al. 2001; Chaba et al. 2002). 
One M. tuberculosis STPK, PknG, has been shown to modulate the host macrophage response to $M$. tuberculosis infection (Cowley et al. 2004; Walburger et al. 2004).

In this work we focus on two STPKs of M. tuberculosis, PknA and PknB. Recent structural data have confirmed the conformational and mechanistic similarity between PknB and the eukaryotic STPKs (Ortiz-Lombardia et al. 2003; Young et al. 2003). Here we demonstrate that the operon containing $p k n A$ and $p k n B$ is transcribed predominantly in exponential phase and that the overexpression of these kinases in mycobacterial cells causes major growth and morphological changes that indicate defects in cell wall synthesis, and possibly in cell division. Using peptide library screening and proteomic methods, we determined the preferred substrate motifs of $\mathrm{PknA}$ and $\mathrm{PknB}$, and identified three in vivo substrates of these kinases. Moderate overexpression of one substrate gene, wag31 (divIVA), altered mycobacterial cell morphology depending on the phosphoacceptor residue encoded by the allele being expressed. These results indicate that $\mathrm{PknA}$ and $\mathrm{PknB}$ are key components of a signal transduction pathway that regulates cell shape and possibly cell division in $M$. tuberculosis via reversible phosphorylation of intracellular proteins. The presence of genes encoding PknB-like proteins in the genomes of a broad range of gram-positive bacteria suggests that this regulatory mechanism is widely conserved among prokaryotes.

\section{Results}

Genome sequence and expression analysis of pknA and $\mathrm{pknB}$

The genes encoding PknA and PknB are located near the chromosomal origin of replication in an apparent operon containing five genes. This operon includes a gene for a protein phosphatase (pst $P$ ), a gene involved in cell shape control $(\operatorname{rod} A)$, a gene involved in peptidoglycan synthesis (pbpA), and $p k n A$ and $p k n B$ (Cole et al. 1998). We identified a single in vivo transcription start site $5^{\prime}$ of pst $P$, consistent with its being the first gene of this transcriptional unit (data not shown). Starting with pstP, the start codon of each gene in this operon overlaps with the stop codon of the preceding gene, indicating coupling of transcription and translation, and thus that the proteins they encode are likely to be produced at similar levels in the cell.

Comparison of the derived amino acid sequences of PknA and PknB from different mycobacterial species shows that the intracellular kinase domains of both proteins are highly conserved among the nonpathogen $M y$ cobacterium smegmatis and two pathogens $M$. tuberculosis and Mycobacterium leprae, with $>85 \%$ identity, suggesting a conserved mechanism of activation and substrate specificity. The amino acid sequences of the Mycobacterium bovis BCG PknA and PknB proteins are $100 \%$ identical to those of $M$. tuberculosis. In all of these mycobacteria, the extracellular domain of $\mathrm{PknB}$ com- prises four PASTA (penicillin-binding and serine/threonine kinase-associated) motifs (Yeats et al. 2002). These analyses of sequence and genome structure suggested the hypothesis that $\mathrm{PknA}$ and $\mathrm{PknB}$ might regulate cells shape and peptidoglycan synthesis, and possibly cell division. These analyses further indicate that this role is conserved among mycobacteria, and that substrates of these kinases are likely to be conserved across mycobacterial species.

To determine the timing of expression of these genes in relation to growth stage, total RNA was purified from cultures of $M$. tuberculosis at serial time points during growth, and quantitative RT-PCR analysis was performed to measure $p k n B$ expression. The mRNA levels of $\operatorname{sig} A$, whose expression is stable during exponential growth and decreases slightly in stationary phase (Manganelli et al. 1999), were also measured in the same RNA samples. Transcription of $p k n B$ was stable from early through late log phase and then decreased 10-fold upon entry into stationary phase (Supplementary Fig. 1). A similar pattern was observed when transcript levels of pst $P$, the first gene in the operon, were measured (data not shown).

\section{Phenotype analysis of mycobacterial strains} overexpressing wild-type and kinase-inactive forms of PknA and PknB

Because $p k n A$ and $p k n B$ were identified as essential genes in $M$. tuberculosis (Sassetti et al. 2003), we examined the phenotypic effects of overexpression of both wild-type and kinase-inactive forms (pknAK42M and pknBK40M) of these genes, under the control of an inducible promoter. A strain of the rapid-growing mycobacterium $M$. smegmatis in which wild-type $M$. tuberculosis $p k n A$ or $p k n B$ was overexpressed grew more slowly than did the control strain containing vector alone (Fig. 1A). The effect on growth of $p k n B$ overexpression was more severe than that of $p k n A$. M. smegmatis cells harboring the kinase-inactive constructs of $p k n A$ or $p k n B$ did not show this growth defect. Overexpression of pknA or $p k n B$ not only inhibited growth, but also markedly diminished viability of $M$. smegmatis, with a more severe effect caused by overexpressing $p k n B$ than $p k n A$ (Fig. 1A). Viability of strains overexpressing the kinase inactive genes was similar to that of control (data not shown). The presence of similar amounts of the native and kinase-inactive forms of $\mathrm{PknB}$ in the overexpression strains indicates that these effects of the native kinase overexpression are the result of their kinase activity (Supplementary Fig. 2). Similar but slightly different phenotypes were seen when these kinases were overexpressed in $M$. bovis BCG (Fig. 1B). As was observed in M. smegmatis, these effects were dependent on the kinase activity of these proteins.

To observe the effects of overexpression of wild-type or mutated $p k n A$ and $p k n B$ on cell morphology, expression of these genes in $M$. smegmatis and $M$. bovis BCG was induced, cells were harvested at early stationary phase and examined by negative stain electron micros- 
Figure 1. Phenotype analysis of mycobacterial strains overexpressing $p k n A$ or $p k n B$. Growth and viability of $M$. smegmatis $(A)$ and $M$. bovis BCG $(B)$ containing a single additional copy of $p k n A$ (filled gray circle), $p k n B(\triangle) p k n A K 2 M(\bullet), p k n B K 40 M(\mathbf{\Delta})$ or plasmid only $(\mathbf{\square})$, under the control of the acetamide-inducible promoter. Cultures were grown to early log phase, diluted to $\mathrm{OD}_{600}=0.02$ and cultured in the presence of inducer. Error bars are $\pm 1 \mathrm{SD}$. In the bar graph, the $p k n B$-overexpression strain is shown in white, the $p k n A$-overexpression strain in gray, and the control in black. $(C)$ Negative stain electron micrographs of $M$. smegmatis and $M$. bovis BCG cells containing a single additional copy of $p k n A, p k n B$, or plasmid under the control of the acetamide-inducible promoter in pMH94. Cultures were grown in the presence of inducer to early stationary phase, at which point they were harvested, fixed, and stained. Bar, $500 \mathrm{~nm}$.
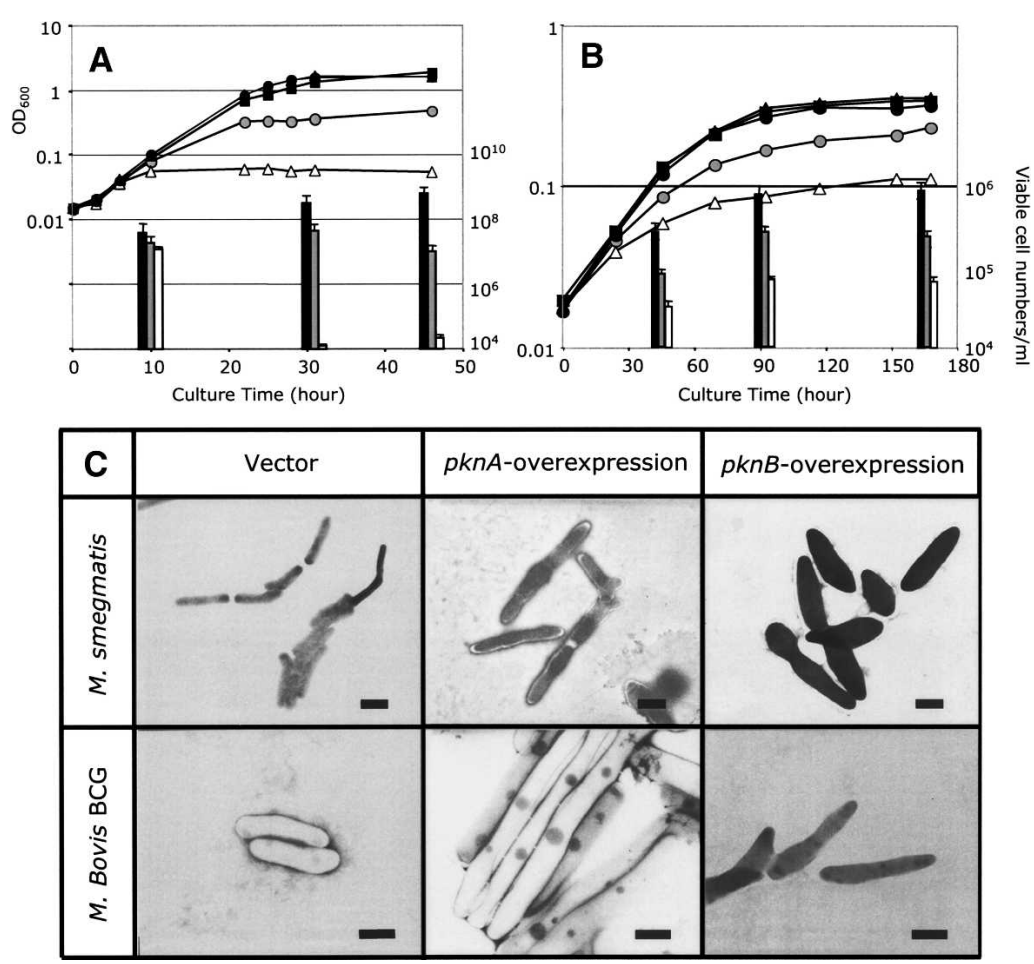

copy. The most striking findings are the broad and irregular shape of the bacilli overexpressing $p k n A$ or $p k n B$ (Fig. 1C). The pknA-overexpressing strains of both $M$. smegmatis and M. bovis BCG form long, broad, and in some cases branched bacilli, with what appear to be incomplete septations, suggesting defects in cell wall synthesis and/or cell division. The $p k n B$-overexpressing strain forms widened, bulging cells of nonuniform diameter, again suggesting effects on cell wall synthesis or cell division. Cells harvested during exponential growth showed similar though less severe phenotypes (data not shown). M. smegmatis and M. bovis BCG cells harboring the kinase-inactive constructs of $p k n A$ or $p k n B$ did not show morphological differences from the control strain containing the vector alone (data not shown).

PknA and PknB have auto- and cross-phosphorylation activity in vitro

The intracellular kinase domains of both proteins were expressed as glutathione-S-transferase (GST) fusion proteins. Inactive forms of these kinases (PknAK42M and PknBK40M) were produced as $6 \mathrm{X}$-His fusion proteins to distinguish the active and mutant forms on SDS-PAGE gels. PknA and PknB were found to have autophosphorylation activity, but the PknAK42M and PknBK40M forms did not (Fig. 2). To assess the ability of these kinases to phosphorylate each other, the wild-type form of one kinase was mixed with the kinase-inactive form of the other. Wild-type PknA phosphorylated kinase-inactive PknB, and wild-type PknB phosphorylated kinaseinactive $\mathrm{PknA}$ and kinase-inactive $\mathrm{PknB}$. These data show efficient intermolecular phosphorylation between these kinases and suggests the possibility that crossphosphorylation between these kinases may occur during signal transduction in vivo.

Peptide library screening to determine the substrate specificity of PknA and $P k n B$

Many eukaryotic kinases show strong substrate selectivity based on the peptide sequence surrounding the phosphoacceptor site. To determine the preferred phosphorylation motif of PknA and PknB, Peptide Library Substrate Analysis was performed (Songyang et al. 1994; Songyang and Cantley 1998). The first step in this analysis is to screen the kinase against a panel of peptide libraries containing a single fixed amino acid in addition to the phosphoacceptor residue. In performing this analysis with PknA and $\mathrm{PknB}$, we found that both kinases showed very strong selectivity for glutamine (Q) at +1 (Fig. 3A). None of the other libraries tested were phosphorylated above background by either kinase. Another striking result of this initial analysis was that both $\mathrm{PknA}$ and PknB greatly preferred to phosphorylate threonine (T) residues rather than serine (S) residues (Fig. 3B). Thus, the initial round of peptide substrate array analysis indicated that the major specificities for both $\mathrm{PknA}$ and PknB were $\mathrm{T}$ as the phosphoacceptor with $\mathrm{Q}$ at the +1 position.

Although this motif appears to be essential for efficient phosphorylation by $\mathrm{PknA}$ or $\mathrm{PknB}$, there are $\sim 4000$ TQ sites encoded in the $M$. tuberculosis genome, indicating additional selectivity for in vivo substrates of 


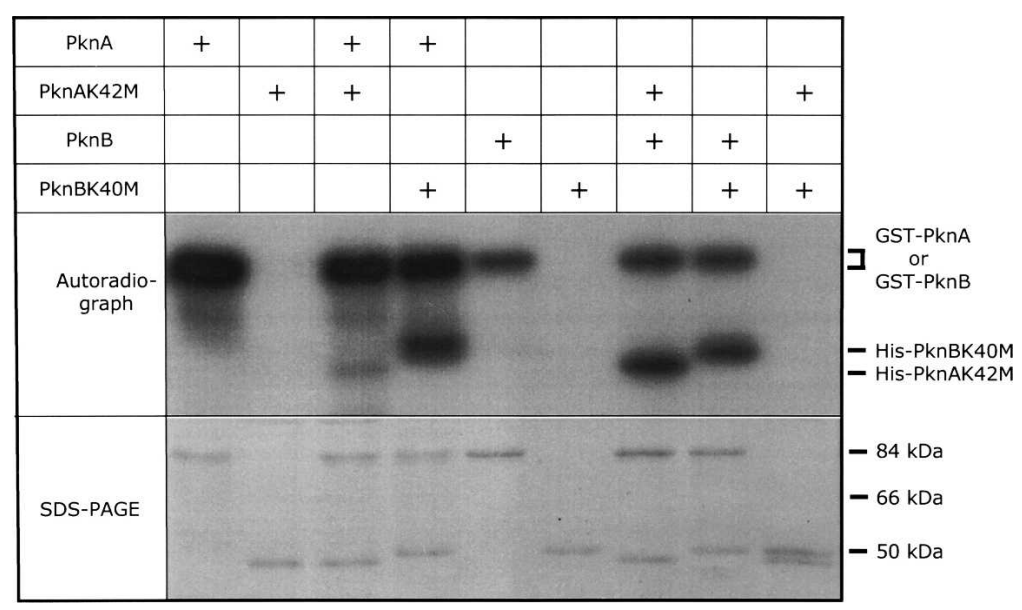

Figure 2. Auto- and cross-phosphorylation activity of PknA and PknB. Recombinant native and variant forms of the intracellular kinase domains of PknA and PknB were assayed in in vitro kinase reactions. Native proteins were purified as GST fusion proteins, and PknAK42M and PknBK40M mutant forms were $6 \mathrm{X}$-His fusion proteins. Coomassie blue staining was performed to verify the amount of protein in each reaction. these kinases. To further define the preferred phosphorylation sequence, a large-scale peptide library screen was performed using the degenerate library with $\mathrm{T}$ as the phosphoacceptor and $\mathrm{Q}$ fixed at the +1 position. This analysis gave similar results for $\mathrm{PknA}$ and $\mathrm{PknB}$, with negative selection against positively charged residues at the +2 and +3 positions and a strong selection for large, hydrophobic amino acids (e.g., phenylalanine $[\mathrm{F}]$, isoleucine [I]) at the +3 and +4 positions (Fig. 3C). The PknB data also indicated positive selection for hydrophobic residues at the +2 position.

Based on these data, a single peptide was synthesized that was predicted to be a good substrate for both kinases, and also to have good solubility. Four additional peptides with amino acid changes predicted to reduce their ability to be phosphorylated were also made (Fig. 3D). Although both kinases strongly preferred the TQ library in the initial screens, substitution of Ala (A) for Q at +1 affected phosphorylation by $\mathrm{PknA}$ minimally; in contrast, this change reduced phosphorylation by $\mathrm{PknB}$ by approximately two-thirds. Consistent with the peptide library results, replacement of the hydrophobic residues at +3 and +4 with Asp (D) severely reduced phosphorylation. In addition, substitution of Asn (N) for Met (M) at +2 had a strong effect for both kinases. In some peptide library experiments, the presence of a basic residue at the -2 position was negatively selected. A peptide substituting $\mathrm{K}$ for $\mathrm{F}$ at -2 was phosphorylated less efficiently by these kinases than was the optimal peptide. These data indicate that both PknA and PknB prefer to phosphorylate peptide sequences containing the motif $\mathrm{X}-\mathrm{X}-\mathrm{X}-\mathrm{X}-\mathrm{T}-\mathrm{Q}-\mathrm{X}-\mathrm{hyd}$ rophobic-hydrophobic, where $\mathrm{X}$ is any amino acid, and the residues surrounding the phosphoacceptor $\mathrm{T}$ are not basic.

\section{Identification of in vivo substrates of PknA and PknB}

To search for in vivo substrates of $\mathrm{PknA}$ and $\mathrm{PknB}$, we used a combination of 2D gel electrophoresis (2DGE), immunoblot analysis with a phospho-(S/T)Q antibody, and mass spectrometry. Despite greater expression of $p k n B$ in exponential versus stationary phase, attempts to identify differences in phosphorylation of $M$. tuberculosis proteins at different growth phases were unsuccessful. We therefore compared the levels of phospho-(S/T)Q proteins in $M$. tuberculosis with and without overexpression of $p k n A$ or $p k n B . M$. tuberculosis cells harboring vector alone, or an inducible $p k n A$ - or $p k n B$-overexpression construct, were grown to early stationary phase, followed by induction of kinase expression for $24 \mathrm{~h}$. Total protein was then extracted, separated by 2DGE, and partially transferred to a PVDF membrane for immunoblot analysis. The residual proteins in the gel were stained with SYPRO-Ruby (Molecular Probes). By superimposing the two images, we were able to pinpoint the protein spots that gave stronger signals in the antiphospho-(S/T)Q immunoblots of proteins from the $p k n A$ - or $p k n B$-overexpression cells. At least five signals were found to be clearly stronger in immunoblots from pknA- or pknB-overexpressing cells (Fig. 4). Three of these five spots were found in both $p k n A$ - and $p k n B$ overexpressing cells. That these immunoblot signals are the result of specific activity of PknA and/or PknB toward authentic in vivo substrates is supported by the presence of weak signals for two spots (II and III) in the control protein sample (Fig. 4; Supplementary Fig. 6).

To identify these substrates of PknA and $P k n B$ and determine their phosphorylation site(s), protein spots corresponding to these immunoblot signals were excised from $2 \mathrm{D}$ gels, run using narrow $\mathrm{pH}$ range IEF strips. When two independent samples of spot I (Fig. 4) in a $p k n B$-overexpression strain were analyzed by liquid chromatography-tandem mass spectrometry, the largest number of peptides in both samples matched sequences from PknB (16 peptides corresponding to $36.1 \%$ of the protein). The only phosphorylated peptide identified was from PknB, where two phosphorylated residues, T171 and T173, were found. These in vivo phosphorylated amino acids are located in the activation loop and are two of the four previously reported sites found to be autophosphorylated in vitro in $\mathrm{PknB}$ produced in Escherichia coli (Young et al. 2003). The sequence at this site, SGNSVT ${ }^{\star} \mathrm{QT}^{\star} \mathrm{AAVI}$ ( ${ }^{\star}$ denotes phosphorylated residues) shows that T171 conforms to the preferred sub- 
Figure 3. Peptide library screening to determine the optimal substrate motif of PknA and PknB. (A) Library pool screening to determine a preferred library for PknA and PknB. The peptide libraries are named by the central fixed phosphoacceptor residue (S or $\mathrm{T})$ and the position and identity of any other fixed amino acid in the library. Where not specified, all positions -4 to +4 relative to the phosphoacceptor are degenerate. Each degenerate peptide library was phosphorylated in the presence of $\left[\gamma_{-}{ }^{32} \mathrm{P}\right] \mathrm{ATP}$ by active PknA or PknB (black bars), or the inactive forms of these kinases (gray bars). (B) Time course of phosphorylation of a TQ versus an SQ library for each protein. $(\bullet)$ PknA + TQ peptide library; (-) PknA + SQ peptide library; ( PknB + TQ peptide library; and $(\mathbf{A})$ PknB + SQ peptide library. Error bars are \pm 1 SD. (C) The TQ degenerate peptide library was incubated with active or inactive PknA or PknB followed by enrichment for phosphopeptides, as described in the Materials and Methods section. The phosphopeptide mixture was subject to quantitative Edman degradation, and the relative amount of each amino acid at each position was determined. Specific amino acids for which positive selectivity was observed are shown. Ratios are the amount of each amino acid from the peptides obtained following incubation with native kinase relative to that incubated with the inactive kinase. $(D)$ In vitro phosphorylation of optimal and variant peptide substrates by $\mathrm{PknA}$ and $\mathrm{PknB}$. In vitro phosphorylation reactions were performed in the presence of $\left[\gamma_{-}{ }^{32} \mathrm{P}\right] \mathrm{ATP}$, and incorporation of ${ }^{32} \mathrm{P}$ was determined. Error bars are $\pm 1 \mathrm{SD}$.
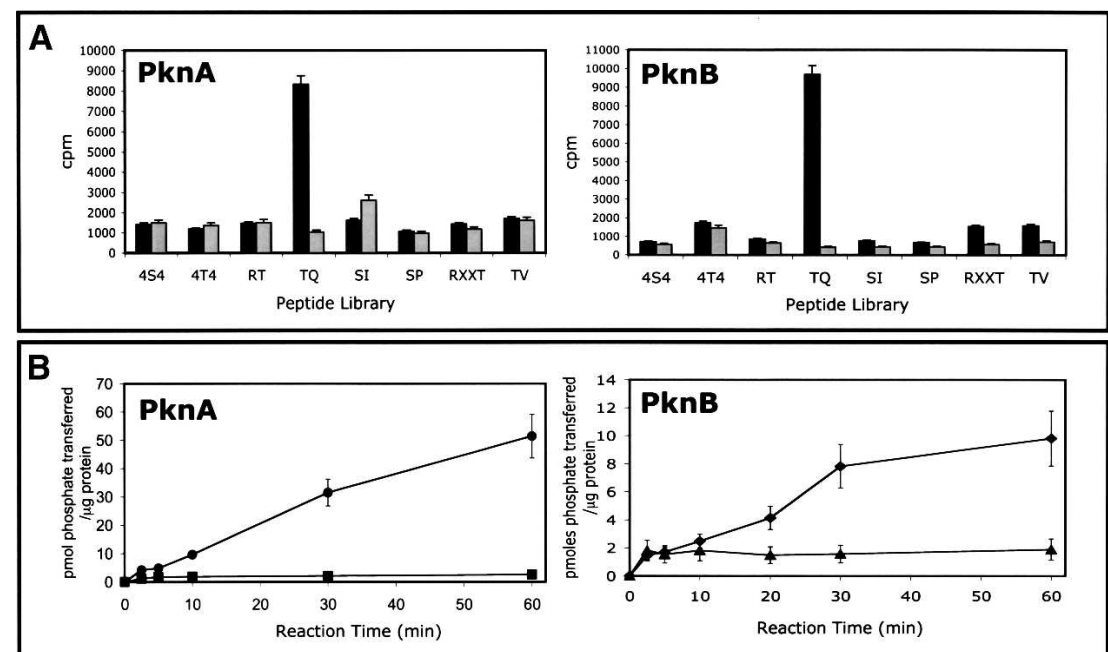

\begin{tabular}{|c|c|c|c|c|c|c|c|c|c|}
\hline \multicolumn{10}{|c|}{ C Substrate specificities of PknA and PknB } \\
\hline & \multicolumn{9}{|c|}{ Position } \\
\hline Kinase & -4 & -3 & -2 & -1 & 0 & +1 & +2 & +3 & +4 \\
\hline PknA & $\begin{array}{l}\mathrm{V}(1.3) \\
\mathrm{P}(1.2)\end{array}$ & $\begin{array}{l}G(1.4) \\
Q(1.3)\end{array}$ & $\begin{array}{l}P(1.7) \\
F(1.5)\end{array}$ & $\begin{array}{l}P(1.6) \\
V(1.3) \\
A(1.3)\end{array}$ & $T$ & Q & $\begin{array}{l}M(1.1) \\
I(1.1)\end{array}$ & $\begin{array}{l}F(2.3) \\
I(1.9) \\
L(1.6) \\
M(1.4)\end{array}$ & $\begin{array}{l}\mathrm{I}(1.3) \\
\mathrm{F}(1.4)\end{array}$ \\
\hline PknB & $\begin{array}{l}\mathrm{Q}(1.3) \\
\mathrm{R}(1.1)\end{array}$ & $\begin{array}{l}\mathrm{G}(1.2) \\
\mathrm{Q}(1.1)\end{array}$ & $\begin{array}{l}\mathrm{G}(1.1) \\
\mathrm{F}(1.1)\end{array}$ & $\mathrm{G}(1.5)$ & $T$ & Q & $\begin{array}{l}\mathrm{I}(1.9) \\
\mathrm{V}(1.7) \\
\mathrm{L}(1.5)\end{array}$ & $\begin{array}{l}\mathrm{I}(2.0) \\
F(1.7) \\
L(1.4) \\
M(1.4)\end{array}$ & $\begin{array}{l}\mathrm{I}(1.4) \\
\mathrm{F}(1.3)\end{array}$ \\
\hline \multicolumn{10}{|c|}{ Ideal Peptide : M-A-R-E-F-G-T-Q-M-F-F-R-A-G-K-K-K } \\
\hline & $\mathrm{No}$ & anc & re nec & select & +2 & for $P$ & and $P$ & & \\
\hline
\end{tabular}
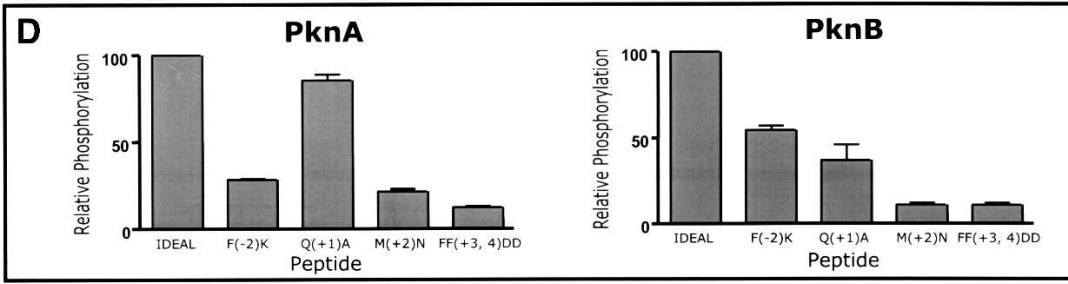

strate motif determined in the peptide library experiments, as does T173 except for the substitution of A for $\mathrm{Q}$ at the +1 position.

Analysis of spot II from the $p k n B$-overexpression strain identified peptides matching several $M$. tuberculosis proteins. Five of these had peptide matches covering $>20 \%$ of the protein sequence. Only one phosphorylated peptide was found, however, which matched the sequence of the conserved hypothetical protein Rv1422. The sequence of this phosphopeptide, R.DVGASEPPVAAT ${ }^{\star}$ QEIPIDGGRPR, has a $\mathrm{Q}$ at the +1 position relative to the phosphoacceptor $\mathrm{T} 325$ residue and hydrophobic residues at $+3(\mathrm{I})$ and $+4(\mathrm{P})$ positions. This sequence is consistent with the motif identified by peptide library screening, and was identified as a high probability candidate substrate in a SCANSITE analysis (Yaffe et al. 2001; Obenauer et al. 2003) that we performed using peptide library screen data.

We conducted three independent analyses of spot III. In the first two experiments the most abundant tryptic peptides were from Wag31 (Rv2145c) (16 peptides corresponding to $31.2 \%$ of the protein in the first analysis, and 47 peptides covering $91.5 \%$ in the second). No phos- phorylation sites were identified, however. On inspection of the Wag31 protein sequence, and based on the identification of a possible phosphorylation site predicted by SCANSITE, it was determined that the tryptic peptide that could contain a PknA or PknB phosphorylation site might be too large to detect. In the third experiment, therefore, spot III was excised from eight separate gels, pooled, and digested with both trypsin and chymotrypsin. In this experiment, Wag31 was again the protein to which most peptides matched, (27 peptides corresponding to $77 \%$ of the protein), and a phosphorylated residue was identified in a peptide with the sequence R.INELDQELAAGGGAGVTPQAT ${ }^{\star}$ QAIPAYEPEPGK. This phosphorylation site is consistent with the preferred motif identified by peptide library screening and is remarkably similar to the phosphorylation site of Rv1422 (AT* QEIP) (see Supplementary Figs. 3, 4 for mass spectra of both phosphopeptides). Wag31 was originally identified as an antigen of $M$. tuberculosis, but comparative sequence analysis indicates that it is a homolog of the cell division/cell shape protein DivIVA of gram-positive bacteria (Hermans et al. 1995; Flardh 2003). We were unable to identify discrete protein spots 


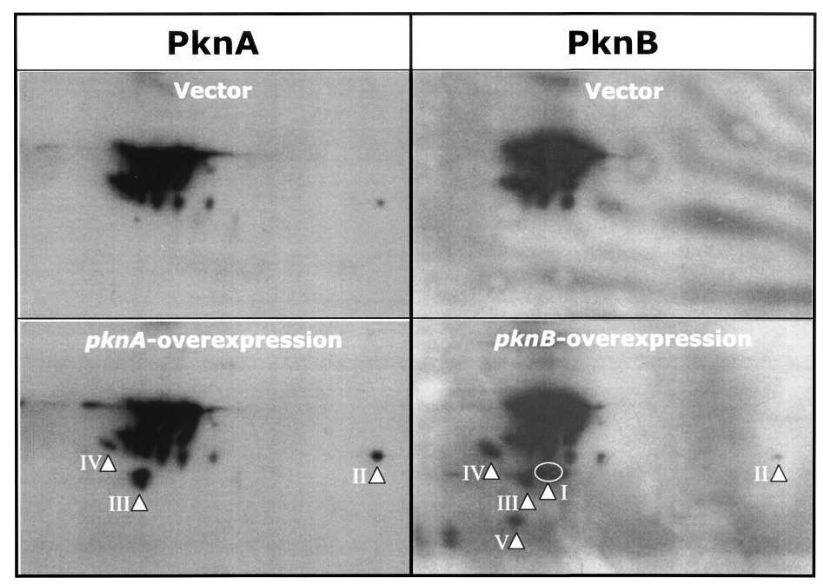

Figure 4. Comparison by immunoblot analysis of phosphoprotein patterns in whole-cell lysates of $M$. tuberculosis cells harboring pMH94 vector alone, pMH94-pknA, or pMH94-pknB grown in the presence of inducer. Proteins were prepared from early stationary phase cultures after $24 \mathrm{~h}$ of induction, and subjected to 2DGE. Protein was then electrotransferred to PVDF membrane, followed by immunoblotting with a phospho(S/T)Q-specific antibody and chemiluminescent detection. Arrowheads indicate the spots that showed stronger signals in gels from $p k n A$ - or $p k n B$-overexpression cells than the control.

in the protein gels corresponding to spots IV and V on the immunoblots, so mass spectrometry analysis was not performed for these spots.

\section{Phosphorylation of Rv1422 and Wag31 by PknA and $P k n B$ in vitro}

To determine whether PknA and/or PknB can directly phosphorylate Rv1422, we conducted in vitro kinase assays with recombinant native Rv1422, and with two variant forms in which the T325 phosphoacceptor residue was replaced with A or S. Immunoblot analysis using the phospho- $(\mathrm{S} / \mathrm{T}) \mathrm{Q}$ antibody showed that the phosphorylation of native Rv1422 occurs at the expected TQ motif (Fig. 5A). Together with the in vivo phosphorylation data, these findings strongly indicate that Rv1422 is an in vivo target of PknA and/or PknB, and that the phosphorylation site is T325. These results also support the strong preference for $\mathrm{T}$ over $\mathrm{S}$ as the phosphoacceptor residue, as found in the peptide library experiments.

In vitro kinase assays were also performed using native Wag31 and variant forms in which the T73 residue of the TQ motif was altered to A or S. Immunoblotting performed with the phospho-(S/T)Q antibody showed that PknA catalyzed a small amount of TQ-specific phosphorylation of native Wag31, but not of the two altered forms (Fig. 5A). PknB alone did not show TQ-specific phosphorylation of Wag31. When both PknA and PknB were included in the reaction, the phosphorylation of the TQ motif of Wag31 was increased, although it remained much lower than the TQ-specific phosphorylation of Rv1422.

To further examine the phosphorylation of Wag31 by
PknA, a Wag31 peptide that includes the T73 phosphoacceptor was synthesized. Peptides in which the T73 residue was altered to $\mathrm{A}$ or $\mathrm{S}$ were also made, and kinase assays were performed. In contrast to the limited phosphorylation of the entire Wag31 protein, the native Wag31 peptide was actively phosphorylated in vitro by PknA, as measured by ${ }^{32} \mathrm{P}$ incorporation (Fig. 5B). The two substituted forms lacking the motif-specific phosphoacceptor $\mathrm{T}$ showed only slight phosphorylation, likely due to nonspecific phosphorylation of another $\mathrm{T}$ residue in the peptide. As was observed in the in vitro kinase assays with Wag31 protein, $\mathrm{PknB}$ did not phosphorylate any form of Wag31 peptide.

\section{Partial depletion of PknA or PknB decreases growth and alters cell shape}

Because they are essential, we were unable to examine the phenotypes of mycobacteria with null mutations in $p k n A$ or $p k n B$. We therefore used an inducible antisense expression system to reduce the amount of $\mathrm{PknA}$ or PknB in the cells. A strong inducible promoter, PnitA (Herai et al. 2004), was used to express antisense $p k n A$ or $p k n B$ sequences from a replicating vector in $M$. smegmatis. Using a PknB-specific antibody, we documented a reduction of $\mathrm{PknB}$ protein to $\sim 50 \%-80 \%$ of the amount present in control cells during exponential phase (Supplementary Fig. 5). This partial depletion of PknA or PknB substantially decreased growth rates in broth culture (Fig. 6A). Microscopic examination of these antisense- $p k n A$ or $-p k n B$ cultures showed narrowing and marked elongation of the mycobacterial cells relative to control cells (Fig. 6B-D). These morphologic effects, which contrast with the broad, bulging phenotypes in the kinase overexpression strains, provide further strong evidence for a role for PknA and PknB in regulating cell shape and possibly cell division.

\section{Overexpressed Rv1422 and Wag31 are specifically phosphorylated in vivo}

To further investigate whether Rv1422 and Wag31 are targets of $\mathrm{PknA}$ and/or PknB in vivo, a second copy of each gene under the control of an inducible promoter was introduced into M. smegmatis and M. bovis BCG. Overexpression of Rv1422 or wag31 in M. smegmatis produced strong phospho-(S/T)Q-specific immunoblot signals relative to signals from blots prepared from control cells containing vector only, indicating specific phosphorylation of the overexpressed protein (Fig. 7A). In $M$. bovis BCG, increases in signal were visible but less substantial in the samples from the strains overexpressing wag31 or Rv1422 (data not shown). Together with the presence of the phospho-specific immunoblot signals from these proteins in the $M$. tuberculosis control strains (Fig. 4; Supplementary Fig. 6), the increase in signal in these substrate overexpression strains indicates that Rv1422 and Wag31 are physiologic targets of these kinases in vivo. 
Figure 5. (A) In vitro phosphorylation of Rv1422 and Wag3 1 by PknA and PknB. Recombinant $6 \mathrm{X}-\mathrm{His}-\mathrm{Rv} 1422$, 6X-His-Rv1422T325A，6X-His-Rv1422T325S，6X-HisWag31, 6X-His-Wag31T73A, or 6X-His-Wag31T73S was incubated with GST-PknA and/or GST-PknB in kinase buffer as described in the Materials and Methods section. After separation in SDS-PAGE gels, protein was electrotransferred to a PVDF membrane, with phosphoprotein detection using a phospho-(S/T)Q antibody and chemiluminescent detection. A 30-sec exposure was required to detect signals from the reaction with Wag31, while only $10 \mathrm{sec}$ of exposure was used for Rv1422. (B) In vitro phosphorylation of synthetic Wag31 peptides by PknA and PknB. Kinase assays were performed in the presence of $\left[\gamma^{-32} \mathrm{P}\right]$ ATP. Five micro-liters was taken at the indicated time points, and incorporation of ${ }^{32} \mathrm{P}$ was determined. (ㅇ) GST-PknA + wild-type Wag31 peptide; (미 GSTPknA + Wag31T73A pep-tide; $(\diamond)$ GST-PknA + Wag31T73S

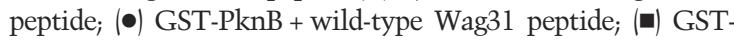
PknB + Wag31T73A peptide; ( ) GST-PknB + Wag31T73S peptide.

The phosphorylation state of Wag31 affects its role in cell shape regulation

Overexpression or depletion of $p k n A$ or $p k n B$ caused morphological changes in mycobacterial cells as described above (Figs. 1, 6). We therefore examined whether the overexpression of Rv1422 or wag31 affected the shape of mycobacterial cells, and if distinct phosphorylation-site alleles had different phenotypes. $M$. smegmatis cells containing wild-type Rv1422- or wag31overexpression constructs were cultured in the presence or absence of inducer and examined by electron microscopy. M. smegmatis strains harboring Rv1422 or wag31 alleles with a mutation that prevents specific phosphorylation of each protein (Rv1422T325A and Wag31T73A), and with a mutation that encodes a protein that mimics constitutive phosphorylation (Rv1422T325E and Wag31T73E), were also analyzed.

Overexpression of Rv1422 did not show clear differences in cell shape when examined at any growth stage.

B
A

\begin{tabular}{|c|c|c|c|c|c|c|c|c|c|}
\hline Pkna & + & & & & & & + & & \\
\hline PknB & & & & + & & & + & & \\
\hline Rv1422 WT & + & & & + & & & + & & \\
\hline Rv1422T325A & & + & & & + & & & + & \\
\hline Rv1422T325S & & & + & & & + & & & + \\
\hline $\begin{array}{l}\text { GST-PknA } \\
\text { or } \\
\text { GST-PknB }\end{array} \longrightarrow$ & & & & & & & & & \\
\hline His-Rv1422 $\longrightarrow$ & 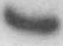 & & & $=$ & & & ent & & \\
\hline PknA & + & & & 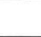 & & & + & & \\
\hline PknB & & & & + & & & + & & \\
\hline Wag31 WT & + & & & + & & & + & & \\
\hline Wag31T73A & & + & & & + & & & + & \\
\hline Wag31T73S & & & + & - & & + & & & + \\
\hline $\begin{array}{l}\text { GST-PknA } \\
\text { or } \\
\text { GST-PknB }\end{array} \rightarrow$ & & & & & & & & & \\
\hline His-Wag31 $\longrightarrow$ & & & & & & & & & \\
\hline
\end{tabular}

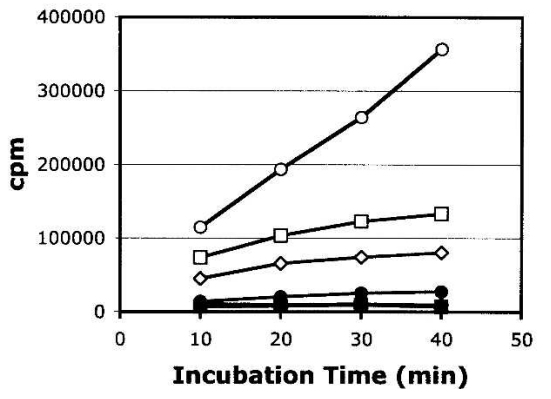

When highly induced during exponential growth or stationary phase, all three alleles of wag31 caused severe morphological changes, which could not be readily distinguished from each other (data not shown). With moderate induction, however, stationary-phase cells expressing the native wag31 allele or the wag31T73E allele produced a large number of short, wide cells compared with control cells containing vector only (Fig. 7B). The shape of these cells is similar though not identical to the broad irregular shape of the $p k n B$-overexpression cells (Fig. 1C). Very few cells containing the wag31T73A allele showed this phenotype. Immunoblot analysis confirmed that similar amounts of each form of the protein were present in each overexpression strain, indicating that this cell shape phenotype is the result of excess phosphorylated Wag31. Moderate expression of the wag31 alleles in exponential phase showed small populations of cells with abnormal morphology, but consistent differences between the alleles were not identified. 


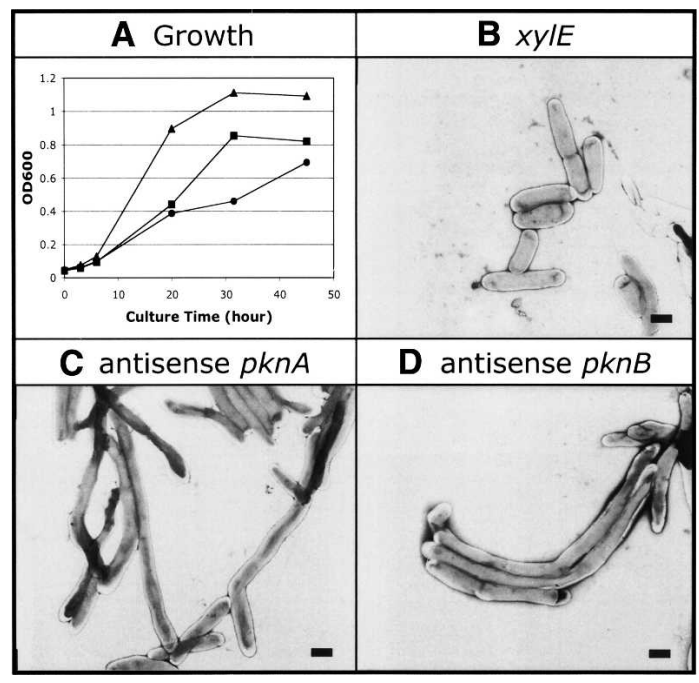

Figure 6. Antisense RNA expression to inhibit PknA and PknB activity in vivo. $M$. smegmatis cells were grown to early exponential phase and expression of antisense $p k n A$ or $p k n B$ was induced. A strain expressing the xylE gene under control of the same promoter was used as a control. Cells were grown to late exponential phase and prepared for microscopic analysis or total protein extraction. (A) Growth curve determined by measurement of $\mathrm{OD}_{600} \cdot(\mathbf{\Delta})$ xylE-expressing strain; $(\bullet)$ antisense-pknAexpressing strain; (-) antisense-pknB-expressing strain. $(B-D)$ Negative stain electron microscopy of kinase antisense-expressing strains and control.

\section{Discussion}

In this work we determined the preferred substrate motif of the M. tuberculosis eukaryotic-like STPKs PknA and $\mathrm{PknB}$, and identified three in vivo protein targets of these kinases, including the key cell division/cell shape protein Wag31 (DivIVA). Together with the morphology, growth, and viability data presented here, these results indicate that these kinases play a major role in regulating cell shape, and likely cell wall synthesis, in mycobacteria. This interpretation is supported by the expression of $p k n A$ and $p k n B$ in an operon that includes $\operatorname{rod} A$ and $p b p A$, genes encoding orthologs of proteins that function in these processes. The markedly higher expression of the $p k n A-p k n B$ operon during exponential growth relative to stationary phase suggests that the regulatory function of these essential kinases is required during active cell replication. This interpretation is consistent with microarray data indicating that these genes are down-regulated in response to nutrient starvation (Betts et al. 2002).

Our results thus identify and provide insight into a novel mechanism for the regulation of cell shape, and possibly cell division, in bacteria. While mycobacteria and other Actinomycetes encode several eukaryotic-like kinases, homologs of $\mathrm{PknB}$ are present in a broad range of gram-positive bacteria, most of which have only one or a few STPKs. Bacillus subtilis, which contains two STPKs, and Streptococcus pneumoniae, which contains one, for example, both encode STPKs whose kinase do- main most closely matches that of PknB. The pknB-like genes in these and other gram-positive bacteria also encode extracellular domains composed of PASTA motifs, as does $p k n B$. This motif, though uncharacterized ex-

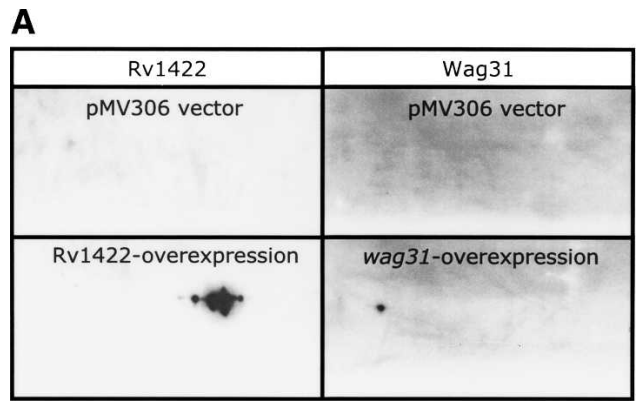

B

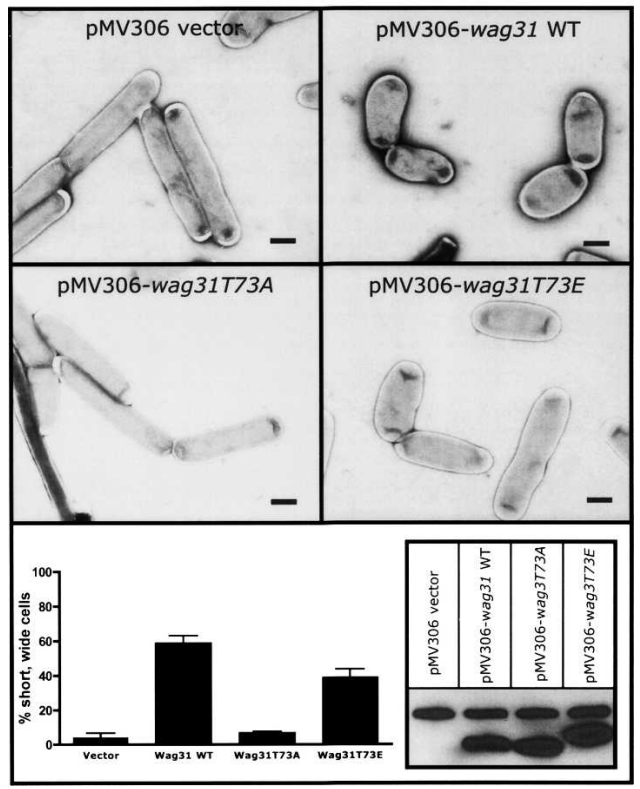

Figure 7. In vivo phosphorylation of Rv1422 and Wag31 and cell shape effects of wild-type and phosphoacceptor-site variants of Wag31 in M. smegmatis. (A) 2D immunoblots probed with a phospho-(S/T)Q-specific antibody of total protein from $M$. smegmatis cells harboring pMV306 plasmid alone, pMV306-Rv1422, or pMV306-wag31. Cells were grown to mid-log phase in the presence of $0.2 \%$ acetamide; total protein was extracted and subjected to 2DGE, immunoblotting, and chemiluminescent detection. For the two left panels, broad-range (pH 3-10) IEF strips were used; for the two panels on the right, narrow-range (pH 4.7-5.9) IEF strips were used to separate Wag31 from other (S/T)Q phosphorylated proteins. (B) Cell morphology phenotype of wag31 overexpression. Genes for M. tuberculosis Wag31, Wag31T73A, or Wag31T73E were expressed in M. smegmatis. Cells were cultured to early stationary phase without inducer, followed by addition of $0.03 \%$ acetamide, and grown for an additional $12 \mathrm{~h}$ prior to harvesting. All micrographs are at $15,000 \times$ magnification. Bar, $500 \mathrm{~nm}$. The bar graph shows the percentage of short, wide cells in each strain, counted in two independent experiments. Error bars are $\pm 1 \mathrm{SD}$. The immunoblot was performed with an anti-Wag31 monoclonal antibody. The upper band in each lane is the endogenous M. smegmatis Wag31, which is 20 amino acids larger than M. tuberculosis Wag31. 
perimentally, has been predicted to interact with cell wall peptidoglycan based on structural analysis of Streptococcus pneumoniae $\mathrm{Pbp} 2 \mathrm{X}$, which contains two PASTA domains, bound to a $\beta$-lactam antibiotic (Gordon et al. 2000; Yeats et al. 2002). In the context of our experimental data, these conserved features strongly support a commonality of function of PknB-like STPKs in regulating cell shape in a broad range of gram-positive bacteria.

The preferred substrate motif of these kinases, defined in the peptide library experiments, has several interesting features. First, the strong preference for $T$ versus $S$ as the phosphoacceptor is unusual, and suggests that serine is not a phosphoacceptor for these kinases in vivo. The selectivity in the region of the motif that is C-terminal to the phosphoacceptor is its other major feature. This includes the preference for $Q$ at the +1 position and for large hydrophobic residues at the +3 and +4 positions, as well as selection against basic residues in these positions. The individual peptide phosphorylation data further support an optimal substrate in which the key sequence constraints are $\mathrm{T}$ (vs. S) as the phosphoacceptor and hydrophobic residues C-terminal to the phosphoacceptor. Interestingly, however, while the preference of $\mathrm{PknB}$ for $\mathrm{Q}$ at the +1 position is supported by these data, the substitution of $\mathrm{A}$ in this position had a small effect on phosphorylation by $\mathrm{PknA}$, suggesting that in vivo substrates of PknA may include proteins that do not have $Q$ at the +1 position.

To identify proteins phosphorylated by these kinases in vivo, we used a proteomic approach to compare $\mathrm{T}^{\mathrm{P}} \mathrm{Q}$ phosphorylated proteins in wild-type versus $p k n A$ - or pknB-overexpression strains of $M$. tuberculosis. Of the five well-localized spots with clearly increased signals in immunoblots of protein from these kinase overexpression strains, three were increased in both the $p k n A$ - and pknB-overexpression strains. This result suggests that these kinases may phosphorylate some of the same proteins, or that they function in a single pathway, with overexpression of either gene increasing the activity of the pathway. Identification of $\mathrm{PknB}$ as the predominant protein from Spot I (present only in samples from $p k n B$ overexpression strain) and identification of two phosphorylated threonine residues in the activation segment that were previously shown to be autophosphorylated in vitro (Boitel et al. 2003; Young et al. 2003), confirmed the value of this approach to identify targets of PknA and PknB.

The second in vivo phosphorylated protein that we identified is a conserved hypothetical protein, Rv1422. Similar proteins are present in many gram-negative and gram-positive bacteria, though none have been functionally characterized. Rv1422 is present in the $M$. tuberculosis chromosome in an apparent operon that encodes a conserved protein of unknown function, a homolog of the UvrC excision repair endonuclease, and a homolog of the Streptomyces coelicolor sporulation-related transcription factor WhiA. Rv1422 homologs are not known to have a role in cell shape or division, and we did not identify a shape phenotype with Rv1422 overexpression.
The presence of whiA in this operon, however, suggests a role, possibly one that is growth stage specific, for Rv1422 in these processes.

The third substrate protein that we identified is Wag31. In vitro, limited but specific phosphorylation of full-length recombinant Wag31 by PknA, and by PknA and $\mathrm{PknB}$ together, but not by PknB alone, was observed. In contrast, PknA efficiently phosphorylated a peptide containing the predicted target sequence from Wag31. These results suggest that Wag31 is a target of PknA, and indicate that the kinase substrate motif of Wag31, which is in the central part of the protein, may be relatively inaccessible in purified Wag31 protein in solution. Wag31 contains coiled-coil domains at both its $\mathrm{N}$ - and C-terminal ends, suggesting that it may form multimers, or interact with other proteins. These data suggest the hypothesis that protein-protein interactions in vivo may alter the conformation of Wag31 and affect the accessibility of the kinase substrate sequence.

Wag31 was originally identified as an antigenic protein of pathogenic mycobacteria that is recognized by serum from persons with leprosy and tuberculosis (Hermans et al. 1995). Recent analyses indicate that this gene is essential, and that it is a homolog of the cell shape/cell division protein DivIVA (Cole et al. 1998; Sassetti et al. 2003). Originally identified as a mini-cell locus in B. subtilis, this protein is required for appropriate septum placement in this species (Cha and Stewart 1997). Inactivation of this gene in $B$. subtilis results in mini-cells, and its overexpression causes a filamentous phenotype. In S. coelicolor, DivIVA $\mathrm{SC}_{\mathrm{SC}}$ is essential and is localized to the growing tips and lateral branches of hyphae where new peptidoglycan assembly occurs (Flardh 2003). Overexpression of this gene causes hyperbranching, with broad cells and abnormal tip growth, a phenotype similar to that of the $p k n A$-overexpressing mycobacterial cells. Similarly, overexpression of the DivIVA ortholog in another rod-shaped Actinmycete, Brevibacterium lactofermentum, results in shortened cells, with DivIVA localized to the poles and to a small extent to the septum.

Alteration of Wag31 activity or localization resulting from phosphorylation by PknA could thus account, in part, for the phenotypes observed in the mycobacterial kinase overexpression and depletion strains. In a model of rod cell shape determination in Corynebacterium/Mycobacterium, new peptidoglycan synthesis occurs only at the cell poles and division site (Daniel and Errington 2003). The observed morphologic effects of both $p k n A / B$ and wag31 overexpression could thus result from altered localization of peptidoglycan synthesis and/or cell division proteins. The morphologic effects seen in the wag31 wild type and wag31T37E-overexpression, but not in the wag31T37A-overexpression strains, indicate that specific phosphorylation of Wag31 affects its role in cell shape control.

The lack of a substantial extracellular domain of PknA, the phosphorylation of Wag31 by PknA but not PknB, and our cross-phosphorylation data suggest a preliminary model in which PknA and PknB are colocalized to particular regions of the mycobacterial cell, possibly 
via interaction of the extracellular domain of $\mathrm{PknB}$ with peptidoglycan or another ligand. PknB would then activate PknA by cross-phosphorylation of its activation loop, with PknA phosphorylating target proteins involved in cell division and cell wall synthesis to alter their function. Our data do not exclude the possibility that PknA and PknB act independently, and additional proteins are certain to be identified that contribute to the PknA and PknB signaling pathways. In particular, the activity of the phosphatase PstP, which has been shown to dephosphorylate the two phosphoacceptor threonine residues in the activation loop of $\mathrm{PknB}$ in vitro (Boitel et al. 2003), may play a key role in modulating the function of these kinases.

Our data indicate that signal transduction mediated by $\mathrm{PknA}$ and $\mathrm{PknB}$ is a novel mechanism for the regulation of cell shape in mycobacteria. The presence of genes encoding PknB-like proteins in a broad range of gram-positive bacteria suggests that this regulatory mechanism may be widely distributed in prokaryotes. Many aspects of this signaling pathway remain to be defined, including characterizing the effects of phosphorylation on target protein function and the identification of additional substrates and other molecules that comprise this signaling pathway.

\section{Materials and methods}

\section{Bacterial strains, media, and growth conditions}

M. smegmatis, M. bovis BCG, and M. tuberculosis cultures were grown at $37^{\circ} \mathrm{C}$ in Middlebrook $7 \mathrm{H} 9$ liquid medium (DIFCO) supplemented with $10 \%$ ADC $(A D C=5 \%[\mathrm{w} / \mathrm{v}]$ bovine serum albumin fraction $\mathrm{V}, 2 \%[\mathrm{w} / \mathrm{v}]$ glucose and $0.85 \%$ $[\mathrm{w} / \mathrm{v}] \mathrm{NaCl}$ ), and $0.05 \%(\mathrm{w} / \mathrm{v})$ Tween-80 (7H9-ADC-Tw), or on Middlebrook 7H9-ADC agar plates. Kanamycin $(50 \mu \mathrm{g} / \mathrm{mL})$ was added to culture media as indicated. For phenotype analysis of $p k n A$ or $p k n B$ overexpression in mycobacteria, each strain was grown in 7H9-ADC-Tw without inducer to late exponential phase, and reinoculated into fresh medium with $0.2 \%(\mathrm{w} / \mathrm{v})$ acetamide. Samples were taken at serial time points for $\mathrm{OD}_{600}$ measurement and plating. E. coli DH5 (Invitrogen) was used as a host strain for cloning experiments, and was grown in LB broth or solid medium with kanamycin $(25 \mu \mathrm{g} / \mathrm{mL})$ or carbenicillin $(100 \mu \mathrm{g} / \mathrm{mL})$ added where appropriate.

Construction of mycobacterial strains expressing pknA, pknB, pknAK42M, pknBK40M, wag31, wag31T73A, and wag31T73E

The coding regions of $p k n A$ and $p k n B$ were amplified by polymerase chain reaction (PCR) with appropriate restriction sites on the $5^{\prime}$ - and $3^{\prime}$-ends using the primers pknA-L and pknA-R, and pknB-L and pknB-R (see Supplementary Table 1 for all primer sequences). PCR products were then cloned into the NdeI site at the $3^{\prime}$-end of the acetamidase control region in pCKAceI (Manabe et al. 1999). The $p k n A$ or $p k n B$ gene and acetamidase control region were then cloned into the mycobacterial integrating vector pMH94 (Lee et al. 1991). In addition to wild-type genes, kinase-inactive constructs in which the ATPbinding domain $\mathrm{K}$ was changed to $\mathrm{M}$ were made for $p k n A$ (pHM94-pknAK42M) and pknB (pMH94-pknBK40M) by two- step overlap PCR using primers pknA-L and pknA K/M-R, and pknA K/M-L and pknA-R. A second PCR reaction using the primary PCR products as templates and pknA-L and pknA-R as primers was then performed. For the $p k n B$ mutant, a similar approach was taken using pknB-L, pknB-R, pknB K/M-R, and pknB K/M-L. The final PCR products were then cloned into pMH94. The sequence of all clones was confirmed by DNA sequencing.

The native wag31 gene, and mutant alleles that encode $\mathrm{A}$ or $\mathrm{E}$ in place of the phosphoacceptor $\mathrm{T}$ (wag31T73A and wag31T73E) were subcloned under control of the acetamide promoter in the integrating vector pMV306. Primers with appropriate restriction sites were used for PCR amplification of the wild-type wag31 gene (Wag31-L and Wag31-R). Mutations in the wild-type gene were made using the QuickChange SiteDirected Mutagenesis kit (Stratagene) using primers wagA216G, wag-anti-A216A, wag-C217G, and wag-anti-C217G. The final constructs, as well as the vector without an insert, were electroporated into $M$. smegmatis, $M$ bovis BCG, or M. tuberculosis H37Rv. The presence of the appropriate insert in each strain was confirmed.

\section{Electron microscopic analysis}

M. smegmatis and $M$. bovis BCG harboring pMH94-pknA, pMH94-pknB, pMH94-pknAK42M, pMH94-pknBK40M, or pMH94 vector alone were grown at $37^{\circ} \mathrm{C}$ with $0.2 \%(\mathrm{w} / \mathrm{v})$ acetamide induction in 7H9-ADC-Tw liquid medium, and harvested at early stationary phase. $M$. smegmatis and $M$. bovis BCG containing pMV306-wag31, pMV306-wag31T73A, pMV306-wag31T73E, or pMV306 vector alone were grown without acetamide in 7H9-ADC-Tw to early stationary phase, at which point $0.03 \%$ acetamide was added, followed by culture for an additional $12 \mathrm{~h}$. Cells were then fixed in PGPC buffer (2.5\% paraformaldehyde, $5.0 \%$ glutaraldehyde, $0.006 \%$ picric acid in $0.1 \mathrm{M}$ cacodylate). For negative staining, the cell suspension was rinsed with PBS buffer, and $5 \mu \mathrm{L}$ of cell suspension was put on a gold grid for $30 \mathrm{sec}$. After removing excess liquid, the grid was placed on a drop of $1 \%$ uranyl acetate buffer and dried. The grid was then examined using a JEOL 1200EX electron microscope.

\section{Recombinant protein expression, purification, and detection}

The kinase domains of PknA and PknB were expressed as $\mathrm{N}$ terminal GST fusion proteins. $M$. tuberculosis $\mathrm{H} 37 \mathrm{Rv}$ genomic DNA was used as the template for amplification of $p k n A$ and $p k n B$, using the primers pknA-GST-F and pknA-GST-R, and pknB-GST-F and pknB-GST-R, respectively, and each PCR product was cloned into pGEX-4T-3 (Amersham). Kinase-inactive forms of these proteins (PknAK42M and PknBK40M) were produced using the pMH94-pknAK42M and pMH94-pknBK40M constructs described above. To distinguish the two forms of these kinases on SDS-PAGE gels, the kinase-inactive constructs were cloned into pET28a (Novagen) and expressed as 6X-His fusion proteins. The sequence of all clones was confirmed by DNA sequencing. GST-PknA and GST-PknB were purified using glutathione-Sepharose 4B resin (Pierce). Kinase-inactive forms of $6 \mathrm{X}$-His-PknA and $6 \mathrm{X}$-His-PknB were purified using Ni-nitrilotriacetic acid (Ni-NTA) resin (Novagen).

Genes for native Rv1422 and Wag31 were amplified by PCR using primers 1422-1 and 1422-4, and Wag-1 and Wag-4, respectively, and cloned into pET28a (Novagen) to produce 6X-His fusion proteins. Substituted forms of Rv1422 or Wag31 in which the $\mathrm{T}$ residue at position $325(\mathrm{Rv} 1422)$ or 73 (Wag31) was re- 
placed with A or S, were constructed using the QuickChange Site-Directed Mutagenesis kit (Stratagene).

The protein levels of PknB and PknBK40M were determined by immunoblot analysis. $M$. smegmatis cells harboring pMH94pknB, pMH94-pknBK40M, or pMH94 vector alone were grown at $37^{\circ} \mathrm{C}$ with $0.2 \%$ acetamide induction in liquid medium and harvested at early stationary phase, and total protein was purified by the TRIzol method. Two micrograms of total protein from each strain was separated by SDS-PAGE and transferred to a PVDF membrane. M. tuberculosis PknB was detected with a mouse antibody produced against the extracytoplasmic region of PknB, with chemiluminescent detection /Cell Signaling Technology). The expression levels of M. smegmatis cells containing pMV306-wag31, pMV306-wag31T73A, or pMV306wag31T73E were also determined by immunoblot analysis, in this case using $5 \mu \mathrm{g}$ of total protein from each construct and the Mab F126-2 (Hermans et al. 1995).

\section{In vitro kinase assays}

For autophosphorylation assays, $200 \mathrm{ng}$ of GST-PknA, GSTPknB, 6X-His-PknAK42M, or 6X-His-PknBK40M protein was incubated in $20 \mu \mathrm{L}$ of kinase buffer $(50 \mathrm{mM}$ Tris- $\mathrm{HCl}$ at $\mathrm{pH} 7.5$, $50 \mathrm{mM} \mathrm{NaCl}, 10 \mathrm{mM} \mathrm{MgCl}_{2}, 10 \mathrm{mM} \mathrm{MnCl}{ }_{2}$ ). The reaction was started by adding $1 \mu \mathrm{Ci}$ of $\left[\gamma^{-32} \mathrm{P}\right] \mathrm{ATP}$, and incubated at $25^{\circ} \mathrm{C}$ for $30 \mathrm{~min}$. To test cross-phosphorylation between PknA and PknB, $200 \mathrm{ng}$ of GST-PknA or GST-PknB was incubated with either 6X-His-PknAK42M (200 ng) or 6X-His-PknBK40M (200 ng). Reactions were terminated by adding SDS gel-loading buffer $(50$ $\mathrm{mM}$ Tris- $\mathrm{HCl}$ at $\mathrm{pH} 6.8,100 \mathrm{mM}$ DTT, $2 \%$ SDS, $0.1 \%$ bromophenol blue, and $10 \%$ glycerol), and the proteins were resolved by SDS-PAGE. Gels were stained by GelCode Blue stain (Pierce), dried and exposed to film.

For immunoblot analysis of substrate proteins, $500 \mathrm{ng}$ of $6 \mathrm{X}$ His-Rv1422, 6X-His-Rv1422T325A，6X-His-Rv1422T325S, 6XHis-Wag31, 6X-His-Wag31T73A, or 6X-His-Wag31T73S was incubated with $300 \mathrm{ng}$ of GST-PknA or GST-PknB in $20 \mu \mathrm{L}$ of kinase buffer, and the reaction was started by adding $1 \mathrm{mM}$ cold ATP. Subsequent steps were performed as described above, except that after separation by SDS-PAGE, immunoblot analysis with chemiluminescent detection was performed with a phospho-(S/T)Q polyclonal antibody (Cell Signaling Technology).

\section{Peptide substrate array analysis}

To define the optimal degenerate peptide library for PknA and PknB, $25 \mathrm{nmol}$ of each peptide library was phosphorylated by $100 \mathrm{ng}$ of $\mathrm{PknA}$ or $\mathrm{PknB}$ or the kinase-inactive forms of these proteins. Reactions were performed in kinase buffer for $30 \mathrm{~min}$ with $100 \mu \mathrm{M}$ cold ATP and $1 \mu \mathrm{Ci}\left[\gamma_{-}{ }^{32} \mathrm{P}\right] \mathrm{ATP}$ at $30^{\circ} \mathrm{C}$. Five microliters of the reaction was spotted on P81 phosphocellulose paper (Whatman) and washed extensively with $1 \%$ phosphoric acid. Incorporated ${ }^{32} \mathrm{P}$ was quantified on a scintillation counter.

Large-scale peptide substrate array analysis was performed using the degenerate TQ libray as described (Songyang and Cantley 1998). Briefly, $10 \mu \mathrm{g}$ of either PknA or PknB was exposed to $400 \mathrm{nmol}$ of the degenerate TQ library in kinase buffer containing a final concentration of $100 \mu \mathrm{M}$ cold ATP with trace $\left[\gamma^{-32} \mathrm{P}\right] \mathrm{ATP}$ in a total volume of $300 \mu \mathrm{L}$ at $30^{\circ} \mathrm{C}$. After $2 \mathrm{~h}$, an additional $10 \mu \mathrm{g}$ of PknA or PknB was added. Once $\sim 1 \%$ of the library was phosphorylated, the reaction was stopped. The reaction was then applied to a DEAE Sephacel column to eliminate unreacted ATP. After binding the reaction to the column, $3 \mathrm{~mL}$ of $30 \%$ acetic acid was added and $500-\mu \mathrm{L}$ fractions were collected. The amount of labeled peptide in each fraction was quantified by scintillation counting. Fractions with the most incorporated ATP were pooled and dried overnight. To separate phosphorylated from nonphosphorylated peptides, a Fe(III)-IDA column was used. The peptides from the DEAE Sephacel column were dissolved in Binding Buffer (50 mM MES at pH 5.5, 1 $\mathrm{M} \mathrm{NaCl}$ ) and applied to a Fe(III)-IDA column equilibrated to $\mathrm{pH}$ 5.5. Peptides were eluted with (1) $4 \mathrm{~mL}$ Binding Buffer, (2) $4 \mathrm{~mL}$ $\mathrm{H}_{2} \mathrm{O}$, (3) $4 \mathrm{~mL} 0.1 \% \mathrm{NH}_{4} \mathrm{OAC}(\mathrm{pH} 9.5)$, (4) 4 mL NH${ }_{4} \mathrm{OAC}(\mathrm{pH}$ 11.5), and (5) 4 mL EDTA ( $\mathrm{pH}$ 8.0). The fractions containing the highest amount of incorporated ATP were pooled and lyophilized, and then redissolved in $\mathrm{H}_{2} \mathrm{O}$. Half the sample was sequenced by Edman degradation. Relative quantities of each amino acid present at each position were determined and standardized as described (Songyang and Cantley 1998; Songyang 2001; Manning et al. 2002). Each experiment was performed in duplicate with extremely similar results.

A peptide with the preferred substrate sequence, and four peptides with substitutions at preferred sites were synthesized (Tufts Core Facility). The sequences of the ideal and variant (change from optimal underlined) peptides are IDEAL, M-A-RE-F-G-T-Q-M-F-F-R-A-G-K-K-K; F(-3)K， M-A-R-E-K-G-T-Q-MF-F-R-A-G-K-K-K; Q(+1)A， M-A-R-E-F-G-T-A-M-F-F-R-A-G-K$\mathrm{K}-\mathrm{K} ; \quad \mathrm{M}(+2) \mathrm{N}, \quad \mathrm{M}-\mathrm{A}-\mathrm{R}-\mathrm{E}-\mathrm{F}-\mathrm{G}-\mathrm{T}-\mathrm{Q}-\mathrm{N}-\mathrm{F}-\mathrm{F}-\mathrm{R}-\mathrm{A}-\mathrm{G}-\mathrm{K}-\mathrm{K}-\mathrm{K} ; \quad \mathrm{FF}(+3$, 4)DD, M-A-R-E-F-G-T-Q-M-D-D-R-A-G-K-K-K. Kinase reactions were performed as described above, with measurement of ${ }^{32} \mathrm{P}$ incorporation at serial time points.

Three Wag31 peptides were also synthesized. The sequences of the native and variant peptides are Wag31 wild type, M-A-VT-P-Q-A-T-Q-A-I-P-A-Y-K-K-K; Wag31T73A， M-A-V-T-P-QA-A-Q-A-I-P-A-Y-K-K-K; Wag31T73S, M-A-V-T-P-Q-A- - -Q-A-I$\mathrm{P}-\mathrm{A}-\mathrm{Y}-\mathrm{K}-\mathrm{K}-\mathrm{K}$. Kinase reactions were performed as described above.

\section{$2 D$ gel, immunoblot, and LC-MS/MS analysis}

For protein extraction, $M$. tuberculosis cells harboring pMH94 plasmid alone, pMH94-pknA, or pMH94-pknB were grown in liquid medium to early stationary phase and then acetamide was added to $0.2 \%$. After $24 \mathrm{~h}$ of incubation, cells were pelleted, washed with $40 \mathrm{mM}$ Tris buffer $(\mathrm{pH} 7.5)$, and resuspended in TRIzol (Invitrogen) in a Lysing Matrix B tube (QBiogene). The samples were lysed in a FastPrep device (QBiogene), and total mycobacterial protein was extracted according to the supplier's manual (Invitrogen). The protein pellet was resuspended in $1 \%$ $(\mathrm{w} / \mathrm{v})$ SDS and purified with the ReadyPrep 2D Cleanup Kit (Bio-Rad). One-hundred micrograms or $200 \mu \mathrm{g}$ of total protein from each sample was rehydrated into isoelectric focusing strips with a $\mathrm{pH}$ range of 3-10 or 4.7-5.9 (Bio-Rad). Isoelectric focusing was performed for 35,000 V-h in a PROTEAN IEF Cell (Bio-Rad).

Second-dimension SDS-PAGE was performed using 10\% Tris- $\mathrm{HCl}$ gels, and proteins were partially electrotransferred to a PVDF membrane. Immunoblot blot analysis was performed using a phospho-(S/T)Q polyclonal antibody (Cell Signaling Technology) as described above. The SDS-PAGE gel containing residual protein was stained with SYPRO-Ruby (Molecular Probes). Images from the immunoblot and stained gel were then superimposed to select protein spots that showed stronger signals in $p k n A$ - or $p k n B$-overexpressing cells.

The protein spots were excised and subjected to a modified in-gel trypsin or trypsin plus chymotrypsin digestion procedure (Shevchenko et al. 1996). The resulting peptides were subjected to electrospray ionization and entered into an LCQ DECA ion-trap mass spectrometer (ThermoFinnigan). Eluting peptides were detected, isolated, and fragmented to produce a tandem mass spectrum of specific fragment ions for each peptide. Peptide sequences and protein identity were determined by matching protein or translated nucleotide databases 
with the acquired fragmentation pattern using Sequest software (ThermoFinnigan).

To examine in vivo phosphorylation of Rv1422 and Wag31, 2DGE was performed on protein samples from mycobacterial cells overexpressing Rv1422 or wag31, followed by immunoblot blot analysis using the anti-phospho-(S/T)Q antibody, as described above, using a $\mathrm{pH} 3-10$ IEF strip for Rv1422 and a $\mathrm{pH}$ 4.7-5.9 IEF strip for Wag31.

\section{Inducible antisense expression}

To deplete PknA and PknB in M. smegmatis, antisense sequences of $p k n A$ or $p k n B$ were cloned under the control of the inducible nitA promoter (PnitA) from Rhodococcus rhodochorus (Herai et al. 2004) in the replicating plasmid pMV261. As a control, the xylE gene of Pseudomonas putida was cloned into the same vector. Primers used for these constructs are MsA261Nit-5, MsA-Xba-3, MsB-261Nit-5, MsB-Xba-3, SdxylE-F, and xylE-R-Xba. Each construct was then transformed into M. smegmatis, and cultured in the presence or absence of $0.1 \% \varepsilon$-caprolactam (inducer). Growth in $7 \mathrm{H} 9$ medium was determined by measuring $\mathrm{OD}_{600}$, and the morphology of the cells were examined by electron microscopy as described above.

\section{Acknowledgments}

We thank Gerald Watts for assistance with electron microscopy and Simon Dove for critical review of the manuscript. This work was supported by Public Health Service grants K08AI53819 to D.W.A., GM56203 to L.C.C., and AI51707 and AI59702 to R.N.H.

\section{References}

Av-Gay, Y. and Everett, M. 2000. The eukaryotic-like Ser/Thr protein kinases of Mycobacterium tuberculosis. Trends Microbiol. 8: 238-244.

Av-Gay, Y., Jamil, S., and Drews, S.J. 1999. Expression and characterization of the Mycobacterium tuberculosis serine/ threonine protein kinase PknB. Infect. Immun. 67: 56765682.

Betts, J.C., Lukey, P.T., Robb, L.C., McAdam, R.A., and Duncan, K. 2002. Evaluation of a nutrient starvation model of Mycobacterium tuberculosis persistence by gene and protein expression profiling. Mol. Microbiol. 43: 717-731.

Boitel, B., Ortiz-Lombardia, M., Duran, R., Pompeo, F., Cole, S.T., Cervenansky, C., and Alzari, P.M. 2003. PknB kinase activity is regulated by phosphorylation in two $\mathrm{Thr}$ residues and dephosphorylation by PstP, the cognate phospho-Ser/ Thr phosphatase, in Mycobacterium tuberculosis. Mol. Microbiol. 49: 1493-1508.

Cha, J.H. and Stewart, G.C. 1997. The divIVA minicell locus of Bacillus subtilis. J. Bacteriol. 179: 1671-1683.

Chaba, R., Raje, M., and Chakraborti, P.K. 2002. Evidence that a eukaryotic-type serine/threonine protein kinase from $M y$ cobacterium tuberculosis regulates morphological changes associated with cell division. Eur. J. Biochem. 269: 10781085.

Cole, S.T., Brosch, R., Parkhill, J., Garnier, T., Churcher, C., Harris, D., Gordon, S.V., Eiglmeier, K., Gas, S., Barry III, C.E., et al. 1998. Deciphering the biology of Mycobacterium tuberculosis from the complete genome sequence. Nature 393: $537-544$.

Cowley, S., Ko, M., Pick, N., Chow, R., Downing, K.J., Gordhan, B.G., Betts, J.C., Mizrahi, V., Smith, D.A., Stokes, R.W., et al. 2004. The Mycobacterium tuberculosis protein serine/ threonine kinase PknG is linked to cellular glutamate/ glutamine levels and is important for growth in vivo. Mol. Microbiol. 52: 1691-1702.

Daniel, R.A. and Errington, J. 2003. Control of cell morphogenesis in bacteria: Two distinct ways to make a rod-shaped cell. Cell 113: 767-776.

Flardh, K. 2003. Essential role of DivIVA in polar growth and morphogenesis in Streptomyces coelicolor A3(2). Mol. Microbiol. 49: 1523-1536.

Gordon, E., Mouz, N., Duee, E., and Dideberg, O. 2000. The crystal structure of the penicillin-binding protein $2 \mathrm{x}$ from Streptococcus pneumoniae and its acyl-enzyme form: Implication in drug resistance. J. Mol. Biol. 299: 477-485.

Herai, S., Hashimoto, Y., Higashibata, H., Maseda, H., Ikeda, H., Omura, S., and Kobayashi, M. 2004. Hyper-inducible expression system for streptomycetes. Proc. Natl. Acad. Sci. 101: 14031-14035.

Hermans, P.W., Abebe, F., Kuteyi, V.I., Kolk, A.H., Thole, J.E., and Harboe, M. 1995. Molecular and immunological characterization of the highly conserved antigen 84 from Mycobacterium tuberculosis and Mycobacterium leprae. Infect. Immun. 63: 954-960.

Koul, A., Choidas, A., Tyagi, A.K., Drlica, K., Singh, Y., and Ullrich, A. 2001. Serine/threonine protein kinases PknF and PknG of Mycobacterium tuberculosis: Characterization and localization. Microbiology 147: 2307-2314.

Lee, M., Pascopella, L., Jacobs Jr., W., and Hatfull, G. 1991. Site-specific integration of mycobacteriophage L5: Integration-proficient vectors for Mycobacterium smegmatis, $M y$ cobacterium tuberculosis and bacille Calmette-Guerin. Proc. Natl. Acad. Sci. 88: 3111-3115.

Leonard, C.J., Aravind, L., and Koonin, E.V. 1998. Novel families of putative protein kinases in bacteria and archaea: Evolution of the 'eukaryotic' protein kinase superfamily. Genome Res. 8: 1038-1047.

Magasanik, B. 1995. Historical perspective. In Two component signal transduction (eds. J. Hoch and T. Silhavy), pp. 1-5. ASM Press, Washington, DC.

Manabe, Y.C. and Bishai, W.R. 2000. Latent Mycobacterium tuberculosis-persistence, patience, and winning by waiting. Nat. Med. 6: 1327-1329.

Manabe, Y.C., Chen, J.M., Ko, C.G., Chen, P., and Bishai, W.R. 1999. Conditional $\sigma$ factor expression, using the inducible acetamidase promoter, reveals that the Mycobacterium tuberculosis sigF gene modulates expression of the 16kilodalton $\alpha$-crystallin homologue. J. Bacteriol. 181: 76297633.

Manganelli, R., Dubnau, E., Tyagi, S., Kramer, F.R., and Smith, I. 1999. Differential expression of $10 \sigma$ factor genes in $M y$ cobacterium tuberculosis. Mol. Microbiol. 31: 715-724.

Manning, B.D., Tee, A.R., Logsdon, M.N., Blenis, J., and Cantley, L.C. 2002. Identification of the tuberous sclerosis complex-2 tumor suppressor gene product tuberin as a target of the phosphoinositide 3-kinase/akt pathway. Mol. Cell 10: 151-162.

Munoz-Dorado, J., Inouye, S., and Inouye, M. 1991. A gene encoding a protein serine/threonine kinase is required for normal development of $M$. xanthus, a Gram-negative bacterium. Cell 67: 995-1006.

Obenauer, J.C., Cantley, L.C., and Yaffe, M.B. 2003. Scansite 2.0: Proteome-wide prediction of cell signaling interactions using short sequence motifs. Nucleic Acids Res. 31: 3635 3641 .

Ortiz-Lombardia, M., Pompeo, F., Boitel, B., and Alzari, P.M. 2003. Crystal structure of the catalytic domain of the $P \mathrm{knB}$ serine/threonine kinase from Mycobacterium tuberculosis. J. Biol. Chem. 278: 13094-13100. 
Kang et al.

Peirs, P., De Wit, L., Braibant, M., Huygen, K., and Content, J. 1997. A serine/threonine protein kinase from Mycobacterium tuberculosis. Eur. J. Biochem. 244: 604-612.

Sassetti, C.M., Boyd, D.H., and Rubin, E.J. 2003. Genes required for mycobacterial growth defined by high density mutagenesis. Mol. Microbiol. 48: 77-84.

Shevchenko, A., Wilm, M., Vorm, O., and Mann, M. 1996. Mass spectrometric sequencing of proteins silver-stained polyacrylamide gels. Anal. Chem. 68: 850-858.

Songyang, Z. 2001. Analysis of protein kinase specificity by peptide libraries and prediction of in vivo substrates. Methods Enzymol. 332: 171-183.

Songyang, Z. and Cantley, L.C. 1998. The use of peptide library for the determination of kinase peptide substrates. Methods Mol. Biol. 87: 87-98.

Songyang, Z., Blechner, S., Hoagland, N., Hoekstra, M.F., Piwnica-Worms, H., and Cantley, L.C. 1994. Use of an oriented peptide library to determine the optimal substrates of protein kinases. Curr. Biol. 4: 973-982.

Walburger, A., Koul, A., Ferrari, G., Nguyen, L., PrescianottoBaschong, C., Huygen, K., Klebl, B., Thompson, C., Bacher, G., and Pieters, J. 2004. Protein kinase G from pathogenic mycobacteria promotes survival within macrophages. Science 304: 1800-1804.

World Health Organization. 2002. Tuberculosis. In Fact Sheet No. 104, pp. 1-3.

Yaffe, M.B., Leparc, G.G., Lai, J., Obata, T., Volinia, S., and Cantley, L.C. 2001. A motif-based profile scanning approach for genome-wide prediction of signaling pathways. Nat. Biotechnol. 19: 348-353.

Yeats, C., Finn, R.D., and Bateman, A. 2002. The PASTA domain: A $\beta$-lactam-binding domain. Trends Biochem. Sci. 27: 438 .

Young, T.A., Delagoutte, B., Endrizzi, J.A., Falick, A.M., and Alber, T. 2003. Structure of Mycobacterium tuberculosis PknB supports a universal activation mechanism for Ser/Thr protein kinases. Nat. Struct. Biol. 10: 168-174. 


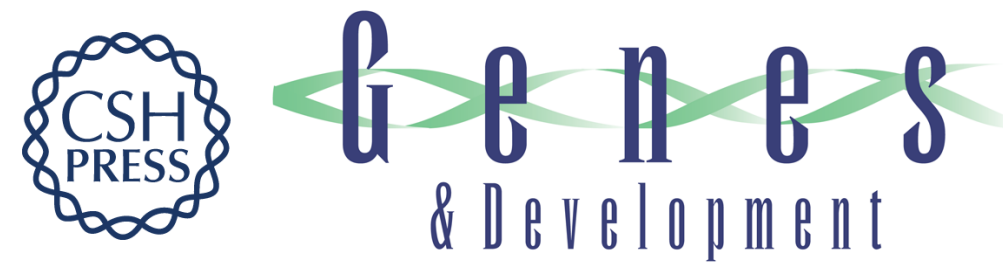

\section{The Mycobacterium tuberculosis serine/threonine kinases PknA and PknB: substrate identification and regulation of cell shape}

Choong-Min Kang, Derek W. Abbott, Sang Tae Park, et al.

Genes Dev. 2005, 19:

Access the most recent version at doi:10.1101/gad.1311105

Supplemental
Material http://genesdev.cshlp.org/content/suppl/2005/06/28/gad.1311105.DC1

References This article cites 33 articles, 9 of which can be accessed free at:

http://genesdev.cshlp.org/content/19/14/1692.full.html\#ref-list-1

License

Email Alerting Receive free email alerts when new articles cite this article - sign up in the box at the top

Service right corner of the article or click here.

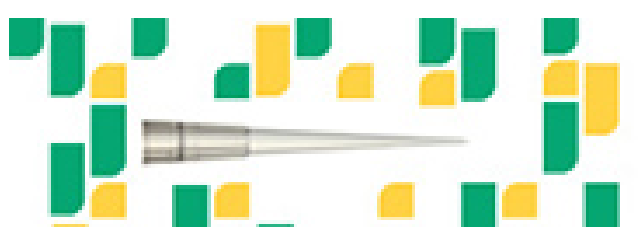

Focused on your science. 